\title{
INTENSIVE CARE UNIT PRESCRIPTIONS MUST FIT RISK FACTORS TO PREVENT STRESS ULCER BLEEDING
}

\author{
Prescrições em unidade de terapia intensiva devem adequar-se aos fatores de risco na prevenção de \\ sangramento por úlcera de estresse
}

\section{Rodolfo Castro Cesar de OLIVEIRA ${ }^{1,2}$, Osvaldo MALAFAIA ${ }^{1 \oplus}$, Fernando Issamu TABUSHI ${ }^{1 \oplus}$, Carlos Roberto NAUFEL JUNIOR ${ }^{2}{ }^{\oplus}$, Elora Sampaio LOURENCO ${ }^{2 \oplus}$, Felipe Yoshio TABUSH ${ }^{2 \odot}$}

ABSTRACT - Background: The physiological stress of critically ill patients can trigger several complications, including digestive bleeding due to stress ulcers (DBSU). The use of acid secretion suppressants to reduce their incidence has become widely used, but with the current understanding of the risks of these drugs, their use, as prophylaxis in critically ill patients, is limited to the patients with established risk factors. Aim: To determine the appropriateness of the use of prophylaxis for stress ulcer bleeding in acutely ill patients admitted to intensive care units and to analyze the association of risk factors with adherence to the prophylaxis guideline. Methods: Retrospective, analytical study carried out in three general adult intensive care units. Electronic medical records were analyzed for epidemiological data, risk factors for DBSU, use of stress ulcer prophylaxis, occurrence of any digestive bleeding and confirmed DBSU. The daily analysis of risk factors and prophylaxis use were in accordance with criteria based on the Guidelines of the Portuguese Society of Intensive Care for stress ulcer prophylaxis. Results: One hundred and five patients were included. Of the patient days with the opportunity to prescribe prophylaxis, compliance was observed in $95.1 \%$. Of the prescription days, $82.35 \%$ were considered to be of appropriate use. Overt digestive bleeding occurred in $3.81 \%$ of those included. The occurrence of confirmed DBSU was identified at $0.95 \%$. Multivariate analysis by logistic regression did not identify risk factors independently associated with adherence to the guideline, but identified risk factors with a negative association, which were spinal cord injury (OR $0.02 p<0.01)$ and shock (OR $0.36 p=0.024)$. Conclusion: The present study showed a high rate of adherence to stress ulcer prophylaxis, but with inappropriate use still significant. In the indication of prophylaxis, attention should be paid to patients with spinal cord injury and in shock.

HEADINGS - Stress, physiological. Hemorrhage. Peptic ulcer. Critical care. Primary prevention.

RESUMO - Racional: O estresse fisiológico dos pacientes críticos pode desencadear várias complicações entre elas o sangramento digestivo por úlcera de estresse (SDUE). O uso de supressores da secreção ácida para reduzir sua incidência passou a ser amplamente utilizado, mas com o atual entendimento dos riscos destes medicamentos sua utilização, como profilaxia em doentes críticos, está limitada aos pacientes com fatores de risco estabelecidos. Objetivos: Determinar a adequação do uso de profilaxia para sangramento por úlcera de estresse em pacientes agudamente enfermos internados em unidades de terapia intensiva e analisar a associação dos fatores de risco com a adesão à diretriz de profilaxia. Métodos: Estudo retrospectivo, analítico, realizado em três unidades de terapia intensiva gerais de adultos. Os prontuários eletrônicos foram analisados para dados epidemiológicos, fatores de risco para SDUE, uso de profilaxia para SDUE, ocorrência de qualquer sangramento digestivo e de SDUE confirmado. A análise diária dos fatores de risco e uso de profilaxia foram de acordo com critérios baseados nas Diretrizes da Sociedade Portuguesa de Cuidados Intensivos para profilaxia da úlcera de estresse. Resultados: foram incluídos 105 pacientes. Dos pacientesdia com oportunidade de prescrição de profilaxia, foi observada adesão em 95,1\%. Dos dias de prescrição foram considerados de uso apropriado $82,35 \%$. Sangramento digestivo visível ocorreu em $3,81 \%$ dos inclú́dos. A ocorrência de SDUE confirmado foi identificada em $0,95 \%$. A análise multivariada por regressão logística não identificou fatores de risco independentemente associados com a adesão à diretriz, mas identificou fatores de risco com associação negativa, que foram lesão da medula espinhal $(O R 0.02 p<0,01)$ e choque $(O R 0.36 p=0.024)$. Conclusão: $O$ presente estudo evidenciou alta taxa de adesão à profilaxia para SDUE, mas com uso inapropriado ainda significativo. $\mathrm{Na}$ indicação de profilaxia deve-se ter atenção aos pacientes com lesão de medula espinhal e choque.

DESCRITORES: Estresse fisiológico. Hemorragia. Úlcera péptica. Cuidados críticos. Prevenção de doenças.

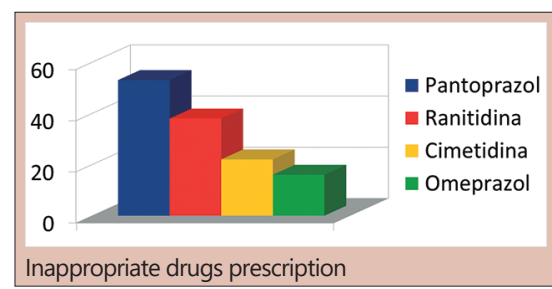

\section{Central message}

Gastrointestinal bleeding prophylaxis due to stress ulcers in hospitalized patients is often used inappropriately. In intensive care unit the risk factors established must be followed to prevent this complication frequently present in these patients.

\begin{tabular}{|l|}
\hline Perspective \\
\hline This study shows high adherence to guidelines for \\
gastrointestinal bleeding prophylaxis due to stress \\
ulcers in ICU and appropriate use of prophylaxis of \\
$82.35 \%$. Considering the high prescriptions of these \\
drugs and the potential adverse events on its use, an \\
opportunity for improvement is identified.
\end{tabular}

Correspondence:

Rodolfo Castro Cesar de Oliveira

E-mail:dr.rodolfo.oliveira@tutanota.com
Financial source: This research was done with the support of the Coordenação de Aperfeiçoamento de Pessoal de Nível Superior Brazil (CAPES) - Financing Code 001.

Conflict of interest: none

Received for publication: 16/11/2020

Accepted for publication: 08/02/2021 
INTRODUCTION

n 1935 Hans Selye, based on experimentation on rats, observed what he called "general adaptation syndrome", which occurred when the organism suffered acute and severe damage by a non-specific agent and which, in its first stage (6-48 h), one of the manifestations was the formation of acute erosions of the digestive tract8. Later the author started to use the term stress, as in his monograph "The Physiology and Pathology of Exposure to Stress" from 1950.

In critically ill patients, factors that impair the integrity of the gastric mucosa are present1. As a result, acute gastric mucosal damage (stress ulcer) or bleeding from stress ulcer may occur. With the observation of this occurrence, the practice of using pharmacological agents for the prevention of gastrointestinal bleeding for stress ulcer (GIBSU) in critical patients has become widespread. Such use has risks and, therefore, should be indicated in patients with an adequate risk-benefit profile. Currently, in critically ill patients hospitalized for acute illness, only those most at risk for GIBSU have an indication for pharmacoprophylaxis ${ }^{10}$. Even so, studies show that inappropriate use still occurs frequently?.

The aim of this study was to determine the appropriateness of the use of prophylaxis for GIBSU in acutely ill patients admitted to intensive care units (ICU) and to analyze the association of risk factors with adherence to prophylaxis for GIBSU.

\section{METHODS}

This is a retrospective, analytical research, carried out in three general ICUs of the University Evangelical Mackenzie Hospital, Curitiba, PR, Brazil, with adult. The sample consisted of all patients discharged or died, from the three ICUs between January and February 2020. Inclusion criteria were: age over 18 years and hospitalization with discharge within the established period. The exclusion criteria were: age below 18 years; patients with convincing indication of non-prophylactic acid suppression upon admission; and those electively admitted to the ICUs after procedures.

\section{Data collect}

Electronic medical records were analyzed to obtain the following data in relation to GIBSU: 1) gender; 2) age; 3) data on admission to the ICU; 4) inpatient sector; 5 ) diagnosis of hospitalization; 6) comorbidities, degree of dependence on the Fungulin scale, Charlson's comorbidity index; 7) presence of risk factors; 8 ) prescription of prophylactic medication; 9) medication used for GIBSU prophylaxis (drug, dose, route and frequency); 10) visible digestive bleeding and endoscopically confirming GIBSU in the ICU; 11) length of stay; and 12) type of exit from the ICU (death or transfer).

Data on risk factors and prophylaxis use for GIBSU were recorded individually for each day of hospitalization. Day patients were no longer registered in cases where they evolved to indicate non-prophylactic acid suppression or for palliation (where prophylaxis for GIBSU could be considered therapeutic futility).

Indications for the use of pharmacological prophylaxis for GIBSU were based on the guidelines of the Portuguese Society of Intensive Care for Stress Ulcer Prophylaxis in the Intensive Care Unit. Prescription of proton pump inhibitor by enteral or parenteral route, $\mathrm{H} 2$ antagonists by enteral or parenteral route was considered prophylaxis for GIBSU in the absence of therapeutic indication.

\section{Statistical analysis}

Was performed using the Chi-square test and Fisher's test to compare categorical variables. Multivariate analysis with logistic regression of risk factors with $p$ less than or equal to $0.1 .95 \%$ confidence intervals were adopted. For the analysis, the software Epi Info v 7.2 (https://www.cdc.gov/ epiinfo/index.html) was used.

\section{RESULTS}

One hundred and seventy-three patients left the ICUs. Of these, 68 were excluded, 32 were indicated for non-prophylactic acid suppression (Table 1), 35 for elective admission to the ICU after therapeutic procedures and one under 18 years of age on admission.

TABLE 1 - Convincing indications for the use of $\mathrm{H} 2$ antagonists or PPIs of patients excluded from the study

\begin{tabular}{|l|c|c|}
\hline \multicolumn{1}{|c|}{ Indication } & $\mathrm{n}$ & $\begin{array}{r}\% \text { of total } \\
\text { excluded }\end{array}$ \\
\hline $\begin{array}{l}\text { Suspected or confirmed upper gastrointestinal } \\
\text { bleeding }\end{array}$ & 13 & $37.14 \%$ \\
\hline $\begin{array}{l}\text { Dual antiplatelet therapy or therapeutic } \\
\text { anticoagulant use }\end{array}$ & 11 & $31.43 \%$ \\
\hline $\begin{array}{l}\text { Chronic use of PPI or H2 antagonist } \\
\text { Known peptic disease in the healing and } \\
\text { maintenance phase }\end{array}$ & 5 & $14.29 \%$ \\
\hline $\begin{array}{l}\text { GERD and complications associated with acidity } \\
\text { GER }\end{array}$ & 3 & $8.57 \%$ \\
\hline
\end{tabular}

After the exclusions, 105 subjects were included. Some characteristics of the sample are described in Table 2.

TABLE 2 - Characteristics of the studied population

\begin{tabular}{|l|c|c|}
\hline \multicolumn{1}{|c|}{ Characteristic } & $\begin{array}{c}\text { \% or average } \\
\text { (min-max, median) }\end{array}$ & $\begin{array}{c}\text { Standard } \\
\text { deviation }\end{array}$ \\
\hline Age (years) & $50.38(18-87,51)$ & 18.74 \\
\hline Male gender & $77.14 \%$ & \\
\hline ICU stay (days) & $8.71(0-62,5)$ & 10.05 \\
\hline Death in the ICU & $46.67 \%$ & \\
\hline Surgical & $67.62 \%$ & \\
\hline Fungulin score at the entrance & $32.51(11-42,34)$ & 5.76 \\
\hline Charlson's comorbidity index & $2.27(0-9,2)$ & 2.51 \\
\hline
\end{tabular}

The most common entry diagnoses were: multiple trauma $(n=17,16.19 \%)$, burn $(n=13,12.38 \%)$, sepsis $(n=13,12.38 \%)$, traumatic brain injury $(n=9,8.57 \%)$ and hemorrhagic stroke $(n=7,6.67 \%$, Table 3).

The most frequent comorbidities were systemic arterial hypertension (24.76\%), diabetes mellitus (13.33\%), alcoholism (10.48\%) and chronic obstructive pulmonary disease (7.62\%, Table 3).

Four occurrences of visible digestive bleeding were identified $(3.81 \%, 95 \% \mathrm{Cl} 1.05-9.47)$. Two of these patients underwent upper digestive endoscopy, one of whom was diagnosed with esophagogastroduodenal ischemia and the other with stress ulcers, which represents a $0.95 \%$ incidence of bleeding confirmed by stress ulcers $(95 \% \mathrm{Cl} 0.02-5.19)$.

Eight hundred and three patient-days were analyzed. Of these, 633 were identified with the opportunity to prescribe prophylaxis for GIBSU with $95.1 \%$ adherence $(95 \% \mathrm{CI}$ 93.1396.53). There were 731 patient-days with prescription of prophylaxis for it. Of these, PPIs were prescribed in $56.77 \%$, in $42.82 \% \mathrm{H} 2$ antagonists and in $0.41 \% \mathrm{PPI}$ and $\mathrm{H} 2$ antagonist association (Table 4). 
TABLE 3 - Diagnosis and comorbidities at the entrance

\begin{tabular}{|c|c|c|}
\hline Diagnosis & $\mathrm{n}$ & $\%$ \\
\hline Polytrauma & 17 & $16.19 \%$ \\
\hline Burn & 13 & $12.38 \%$ \\
\hline Sepsis & 13 & $12.38 \%$ \\
\hline Traumatic brain injury & 9 & $8.57 \%$ \\
\hline Hemorrhagic stroke & 7 & $6.67 \%$ \\
\hline Pneumonia & 4 & $3.81 \%$ \\
\hline Acute abdomen & 3 & $2.86 \%$ \\
\hline Ischemic stroke & 3 & $2.86 \%$ \\
\hline Seizure & 3 & $2.86 \%$ \\
\hline Status epilepticus & 3 & $2.86 \%$ \\
\hline Respiratory failure & 3 & $2.86 \%$ \\
\hline Acute pulmonary edema & 2 & $1.9 \%$ \\
\hline White weapon injury & 2 & $1.9 \%$ \\
\hline Acute renal failure & 2 & $1.9 \%$ \\
\hline Neoplasm of the central nervous system & 2 & $1.9 \%$ \\
\hline Retropharyngeal abscess & 1 & $0.95 \%$ \\
\hline Abscess of the central nervous system & 1 & $0.95 \%$ \\
\hline Shock & 1 & $0.95 \%$ \\
\hline Cholangitis & 1 & $0.95 \%$ \\
\hline Coma & 1 & $0.95 \%$ \\
\hline Firearm injury & 1 & $0.95 \%$ \\
\hline Fournier syndrome & 1 & $0.95 \%$ \\
\hline Subdural hematoma & 1 & $0.95 \%$ \\
\hline Hemoptysis & 1 & $0.95 \%$ \\
\hline Subarachnoid hemorrhage & 1 & $0.95 \%$ \\
\hline Normobaric hydrocephalus & 1 & $0.95 \%$ \\
\hline Arterial hypertension & 1 & $0.95 \%$ \\
\hline Nephrolithiasis & 1 & $0.95 \%$ \\
\hline Acute arterial occlusion & 1 & $0.95 \%$ \\
\hline Pancreatitis & 1 & $0.95 \%$ \\
\hline Diabetic foot & 1 & $0.95 \%$ \\
\hline Pneumothorax & 1 & $0.95 \%$ \\
\hline Bladder bleeding after cancer surgery & 1 & $0.95 \%$ \\
\hline Face trauma & 1 & $0.95 \%$ \\
\hline Total & 105 & $100 \%$ \\
\hline Comorbidity & $\mathrm{n}$ & $\%$ \\
\hline Systemic arterial hypertension & 26 & $24.76 \%$ \\
\hline Diabetes mellitus & 14 & $13.33 \%$ \\
\hline Alcoholism & 11 & $10.48 \%$ \\
\hline Chronic obstructive pulmonary disease & 8 & $7.62 \%$ \\
\hline Stroke & 6 & $5.71 \%$ \\
\hline Dyslipidemia & 6 & $5.71 \%$ \\
\hline Epilepsy & 6 & $5.71 \%$ \\
\hline Chronic kidney failure & 6 & $5.71 \%$ \\
\hline Hypothyroidism & 5 & $4.76 \%$ \\
\hline Metastatic neoplasia & 5 & $4.76 \%$ \\
\hline Coronary artery disease & 4 & $3.81 \%$ \\
\hline Obesity & 4 & $3.81 \%$ \\
\hline Drug addiction & 3 & $2.86 \%$ \\
\hline Human immunodeficiency virus infection & 3 & $2.86 \%$ \\
\hline Nephrolithiasis & 3 & $2.86 \%$ \\
\hline Smoking & 3 & $2.86 \%$ \\
\hline Asthma & 2 & $1.90 \%$ \\
\hline Chagas disease & 2 & $1.90 \%$ \\
\hline Dementia & 1 & $0.95 \%$ \\
\hline Depression & 1 & $0.95 \%$ \\
\hline Peripheral obstructive arterial disease & 1 & $0.95 \%$ \\
\hline Parkinson's disease & 1 & $0.95 \%$ \\
\hline Spondylitis & 1 & $0.95 \%$ \\
\hline Schizophrenia & 1 & $0.95 \%$ \\
\hline Atrial fibrillation & 1 & $0.95 \%$ \\
\hline Spine fracture & 1 & $0.95 \%$ \\
\hline Chronic viral hepatitis & 1 & $0.95 \%$ \\
\hline Previous acute myocardial infarction & 1 & $0.95 \%$ \\
\hline Congestive heart failure & 1 & $0.95 \%$ \\
\hline Leukemia & 1 & $0.95 \%$ \\
\hline Lymphoma & 1 & $0.95 \%$ \\
\hline Cerebral palsy & 1 & $0.95 \%$ \\
\hline Klinefelter syndrome & 1 & $0.95 \%$ \\
\hline Peripheral venous thrombosis & 1 & $0.95 \%$ \\
\hline Extrapulmonary tuberculosis & 1 & $0.95 \%$ \\
\hline
\end{tabular}

TABLE 4 - Doses of drugs prescribed for GBSU prophylaxis

\begin{tabular}{|c|c|c|}
\hline Medication & Dose, route and schedule & $\begin{array}{c}\text { Prescription } \\
\text { days }\end{array}$ \\
\hline Pantoprazole & $40 \mathrm{mg}$ IV q24hr & 382 \\
\hline Pantoprazole & $40 \mathrm{mg} \mathrm{IV} \mathrm{q12hr}$ & 7 \\
\hline Ranitidine & $50 \mathrm{mg}$ IV q8hr & 156 \\
\hline Ranitidine & $150 \mathrm{mg} \mathrm{SG} \mathrm{q12hr}$ & 29 \\
\hline Ranitidine & $50 \mathrm{mg}$ IV q12hr & 24 \\
\hline Ranitidine & $150 \mathrm{mg} \mathrm{VO} \mathrm{q12hr}$ & 10 \\
\hline Ranitidine & $50 \mathrm{mg}$ IV q24hr & 2 \\
\hline Cimetidine & $300 \mathrm{mg} \mathrm{IV} \mathrm{q8hr}$ & 73 \\
\hline Cimetidine & $300 \mathrm{mg}$ IV q12hr & 13 \\
\hline Cimetidine & $300 \mathrm{mg}$ IV q6hr & 6 \\
\hline Omeprazole & $20 \mathrm{mg} \mathrm{VO} \mathrm{q24hr}$ & 24 \\
\hline Omeprazole & $20 \mathrm{mg} \mathrm{SG} \mathrm{q24hr}$ & 1 \\
\hline Omeprazole & $40 \mathrm{mg} \mathrm{VO} \mathrm{q24hr}$ & 1 \\
\hline Pantoprazole + ranitidine & $40 \mathrm{mg} \mathrm{IV} \mathrm{q24hr+} \mathrm{50} \mathrm{mg} \mathrm{IV} \mathrm{q8hr}$ & 3 \\
\hline
\end{tabular}

Of the days of prophylaxis prescription, $82.35 \%(95 \%$ $\mathrm{Cl} 79.42-84.95)$ were considered appropriate and the others inappropriate.

The analysis of the association of risk factors for GIBSU with adherence to prophylaxis in patients with indication is shown in Table 5.

TABLE 5 - Analysis of the association of risk factors for GIBSU and adherence to prophylaxis

\begin{tabular}{lcc}
\hline \multicolumn{1}{c}{ Risk factor } & OR & p \\
\hline Mechanical ventilation & 1.48 & 0.392 \\
Significant coagulopathy & 0.36 & 0.056 \\
\hline $\begin{array}{l}\text { Sepsis } \\
\text { Burn }>35 \% \text { total body surface }\end{array}$ & 1.36 & 0.437 \\
$\begin{array}{l}\text { Spinal cord injury } \\
\begin{array}{l}\text { Cranioencephalic trauma with Glasgow coma scale less } \\
\text { than 9 }\end{array}\end{array}$ & 0.06 & 0.042 \\
\hline $\begin{array}{l}\text { Acute or chronic renal failure with renal replacement } \\
\text { therapy }\end{array}$ & 0.39 & 0.026 \\
$\begin{array}{l}\text { Corticosteroid use }>\text { hydrocortisone } 250 \text { mg daily or } \\
\text { equivalent }\end{array}$ & 0.52 & 0.203 \\
$\begin{array}{l}\text { Polytrauma with trauma severity index 16 points or more } \\
\text { Shock }\end{array}$ & 0.47 & 0.571 \\
\hline
\end{tabular}

The multivariate analysis of the association of risk factors for GIBSU showed a negative association of spinal cord injury $(O R=0.02, p<0.001)$ and shock $(O R=0.36, p=0.024)$ with adherence to GIBSU prophylaxis. Burn $>35 \%$ and cranioencephalic trauma resulted in $O R=3.03, p 0.144$ and $\mathrm{OR}=0.18, \mathrm{p}=0.06$, respectively.

\section{DISCUSSION}

The population analyzed was adult patients, acutely ill hospitalized in the ICU. From the analysis of the epidemiological data it can be seen that the patients were predominantly surgical and men, with an average age of 50 years. Considering that the median of the Fungulin score was 34, it is understood that the majority had a degree of dependence compatible with intensive and semi-intensive care ${ }^{3}$.

Regarding the occurrence of digestive bleeding, there was a record of four visible bleeds, that is, 3.81\% $(95 \% \mathrm{Cl}$ 1.05-9.47), and in only two cases did upper gastrointestinal endoscopy be performed, and a confirmed case of digestive bleeding from stress ulcers $(0.95 \%)$.

Considering the retrospective methodology of the research and based only on the electronic medical record, it cannot be said that only these cases of digestive bleeding are treated, as bleedings may have occurred and not have been properly registered. Diagnostic confirmation of the 
bleeding etiology may present difficulties in the population of critically ill patients, in view of the risk of displacement and complications during the transfer between the ICU and the diagnostic sector. Studies that were based on endoscopic evaluation found higher data than in the present study, such as Kumar \& Sudhakar ${ }^{4}$ that identified $4.35 \%$ of clinically evident GIBSU.

Like all medication, drug prophylaxis for GIBSU should be indicated considering the risk-benefit profile. The inappropriate prescription has several potential problems, such as the risk of adverse events related to the drugs used (and with them the damage to patients, cost of treatment of adverse events and bed occupation for this treatment), as well as the cost of these medications which, although it is not individually high, considering the frequency of use, it can add a significant amount to the institution and the health system.

Considering that the medications of choice for the prophylaxis of GIBSU in the most recent guidelines are PPIs, the predominance of their use, especially pantoprazole, is expected ${ }^{5,10}$. It was observed that the predominance of the use of PPIs was also maintained in the subgroup of prescriptions considered inappropriate.

Several different dosages per drug were observed. Some can be explained in view of the patients' own conditions, such as dose adjustments of $\mathrm{H} 2$ antagonists in case of renal failure. There are more widely known risk factors. The analysis of the association of risk factors for GIBSU with adherence to prophylaxis identified burns $>35 \%$ of the body surface as a factor associated with adherence, but this association was not maintained after the multivariate analysis. Burned patients were identified from the beginning of studies with GIBSU as being at risk, so much so that in their study published in 1994, Cook et $\mathrm{al}^{2}$ sought to identify risk factors and excluded the recommendation not to use prophylaxis for GIBSU in patients with burns $>30 \%$.

With the multivariate analysis of risk factors, the presence of spinal cord injury and shock demonstrated an independent and negative association with adherence to the prescription of prophylaxis of GIBSU. Santos et al. ${ }^{7}$ observed in their study an association of adherence with mechanical ventilation and coagulopathy, and negative with anticoagulation. In the present study, patients on anticoagulation were excluded because it was understood that their use would be a convincing indication for the use of $\mathrm{H} 2$ antagonists or PPIs.

\section{CONCLUSION}

The present study showed a high rate of adherence to prophylaxis for GIBSU, but with inappropriate use still significant. In the indication of prophylaxis, special attention should be paid to patients with spinal cord injury and shock.

REFERENCES

1. Cook D, Guyatt G. Prophylaxis against upper gastrointestinal bleeding in hospitalized patients. New England Journal of Medicine, v. 378, n. 26, p. 2506-2516, 2018. DOI: 10.1056/NEJMra1605507

2. Cook DJ, et al. Risk Factors for Gastrointestinal Bleeding in Critically III Patients. New England Journal of Medicine, v. 330, n. 6, p. 377-381, 1994. DOI: 10.1056/NEJM199402103300601

3. Fugulin FMT, Gaidzinski RR, Kurcgant P. Sistema de classificação de pacientes: identificação do perfil assistencial dos pacientes das unidades de internação do HU-USP. Revista Latino-Americana de Enfermagem, v. 13, n. 1, p. 72-78, 2005. DOI: 10.1590/s0104-11692005000100012

4. Kumar A, Sudhakar G. Upper gastrointestinal lesions and bleed in burn injuries: An endoscopic evaluation. Indian Journal of Burns, v. 22, n. 1 , p. 72 , 2014. DOI: $10.4103 / 0971-653 x .147012$

5. MendesJJ,etal.SociedadePortuguesadeCuidadosIntensivosguidelines for stress ulcer prophylaxis in the intensive care unit. Revista Brasileira de Terapia Intensiva, v. 31, n. 1, p. 5-14, 2019. DOI: 10.5935/0103507X.20190002

6. Rafinazari N, et al. Adherence to stress-related mucosal damage prophylaxis guideline in patients admitted to the Intensive Care Unit. Journal of Research in Pharmacy Practice, v. 5, n. 3, p. 186, 2016. DOI: 10.4103/2279-042x.185728

7. Santos Y, de AP dos et al. Adesão a um protocolo de profilaxia de úlcera de estresse em pacientes críticos: estudo de coorte prospectiva. Revista Brasileira de terapia intensiva, v. 32, n. 1, p. 37-42, 2020. DOI: 10.5935/0103-507x.20200007

8. Selye HA. Syndrome produced by Diverse Nocuous Agents. Nature, v. 138, n. 3479, p. 32-32, 1936. DOI: 10.1038/138032a0

9. Shahbazi F, Karimpur H, Hosseini E. Implementation of Stress Ulcer Prophylaxis(SUP)inan Intensive Care Unit(ICU).Journal ofPharmaceutical Research International, v. 31, n. 6, p. 1-7, 2019. DOI: 10.9734/jpri/2019/ v31i630326

10. YeZ, et al. Gastrointestinal bleeding prophylaxis for critically ill patients: A clinical practice guideline. The BMJ, v. 368, 2020. DOI: 10.1136/bmj.16722 